\title{
TAHANAN GERAK DAN GERAK PITCHING KAPAL PENANGKAP IKAN BERDASARKAN BENTUK LINGGI HALUAN
}

\author{
Resistance and Pichting Motion Based on Bow Shape of Fishing Vessels \\ Oleh: \\ Tri Nanda Citra Bangun ${ }^{1 *}$, Yopi Novita ${ }^{1}$, Budhi Hascaryo Iskandar ${ }^{1}$ \\ ${ }^{1}$ Departemen Pemanfaatan Sumberdaya Perikanan, FPIK- \\ IPB, Bogor \\ *Korespondensi penulis: trinanda@apps.ipb.ac.id
}

\begin{abstract}
ABSTRAK
Desain kapal penangkap ikan di Indonesia sangat beragam, salah satu keragamannya terletak pada bentuk linggi haluan kapal. Bentuk linggi yang sesuai dapat meningkatkan performa kinerja kapal. Penelitian ini bertujuan untuk mengestimasi kemampuan kapal berdasarkan bentuk linggi haluannya terhadap tahanan dan performa gerak pitching kapal. Tiga bentuk linggi haluan yang digunakan dalam penelitian ini yaitu Raked Bow Tegak (RBT), Raked Bow Landai (RBL), dan Spoon Bow (SB) yang dikombinasikan dengan bentuk kasko u-bottom. Hasil penelitian menunjukkan bahwa berdasarkan tahanan kasko, bentuk linggi haluan RBT cenderung menghasilkan tahanan yang lebih tinggi, diikuti oleh RBL, dan SB. Berdasarkan performa gerak pitching kapal, bentuk linggi haluan SB cenderung menghasilkan gerak pitching yang lebih tinggi, diikuti oleh RBL dan RBT.
\end{abstract}

Kata kunci: bentuk linggi, kapal perikanan, gerak pitching, tahanan kapal.

\begin{abstract}
Design of fishing vessels in Indonesia is very diverse, one of which lies in the shape of the bow height of the ship. The form of the bow can improve the performance of the ship's performance. This study aims to estimate the ship's ability based on the shape of the bow's height against the resistance and show in the ship's pitching motion. The three forms of bow used in this study are the Upright Raked Bow (RBT), Sloping Raked Bow (RBL), and the Spoon Bow (SB) combined with the u-bottom hull form. The results showed that based on the resistance of the rafters, the shape of the bow height of the RBT tended to produce higher resistance, followed by RBL and SB. Based on the pitching motion of the ship, the shape of the $S B$ bow height tends to afford a higher pitching motion, followed by $R B L$ and $R B T$.
\end{abstract}

Key words: bow form, fishing vessel, pitching motion, resistance.

\section{PENDAHULUAN}

Desain kapal penangkap ikan di Indonesia sangat beragam. Hasil kajian pada penelitian Bangun et al. (2017), diketahui bahwa perbedaan desain kapal berdasarkan kearifan lokal dan kebiasan turuntemurun pada setiap daerah. Putra et al. (2020) menjelaskan bahwa kapal memiliki keragaman yang meliputi bentuk, desain dan juga ukuran yang dapat mempengaruhi karakteristik dari kapal penangkap ikan. Salah satu pembeda pada bagian desain kapal terletak pada bentuk linggi haluannya. Mengacu pada penelitian Bangun et al. (2017), bentuk linggi haluan kapal yang umum digunakan berbentuk raked bow tegak (RBT), raked bow landai (RBL) dan spoon bow (SB).

Bentuk linggi haluan kapal penangkap ikan akan menentukan performa kinerja kapal saat beroperasi di laut. Kinerja gerak laju kapal akan mempengaruhi besarnya tahanan gerak kapal 
(Djatmiko et al. 1983). Selain tahanan gerak kapal, bentuk linggi haluan kapal juga dapat mempengaruhi gerak pitching kapal (Bhattacharyya 1978).

Luasnya wilayah perairan laut di Indonesia menjadikannya memiliki keragaman karakteristik perairan, khusunya karakteristik perairan daerah penangkapan ikan. Kondisi perairan laut yang berbeda akan menghasilkan tinggi gelombang yang berbeda pula. Menurut Ma'ruf dan Pranatal (2020), karakteristik gelombang merupakan faktor beban luar yang sangat berpengaruh pada suatu kapal. Dalam hal ini bentuk linggi haluan kapal penangkap ikan seharusnya dirancang sesuai dengan karakteristik daerah penangkapan.

Berdasarkan pemaparan diatas, maka perlu dilakukan suatu kajian untuk mengestimasi kemampuan tiap bentuk linggi haluan terhadap tahanan gerak kapal dan performa gerakan pitching kapal. Penelitian ini juga merupakan penelitian lanjutan yang telah dilakukan Bangun et al. (2017). Hasil penelitian ini dapat memberikan gambaran performa masing-masing bentuk linggi pada kondisi perairan yang berbeda. Parameter yang dianalisis pada penelitian ini adalah tahanan gerak dan gerak pitching kapal penangkap ikan.

\section{METODE PENELITIAN}

Bentuk linggi haluan yang banyak ditemukan di Indonesia adalah bentuk RBT, RBL, dan SB. Selanjutnya bentuk linggi haluan kapal dikombinasikan dengan bentuk kasko. Mengacu pada Rouf (2004) dalam Dariansyah et al. (2017) dan Novita dan Rahman (2008) dalam Dariansyah et al. (2020), bentuk kasko yang banyak digunakan adalah bentuk kasko U-bottom. Bentuk linggi haluan kapal dikombinasikan dengan bentuk kasko disampaikan pada Gambar 1-3. Ketiga kapal pada gambar tersebut menggunakan dimensi kapal yang sama, yaitu LOA $=18 \mathrm{~m}, \mathrm{~B}=4,6 \mathrm{~m}, \mathrm{D}=1,8 \mathrm{~m}$, dan $\mathrm{T}=1,2$ m. Melalui data tersebut, penelitian ini dilakukan proses penelitian lanjutan pada bulan Juli 2020 guna memperoleh hasil tahanan gesek dan performa pitching kapal sesuai dengan bentuk linggi haluannya. Dalam penelitian ini, juga dilakukan perhitungan terhadap coefficient of fineness, tahanan kasko dan performa gerak pitching pada ketiga kapal tersebut. Perhitungan coefficient of fineness dilakukan berdasarkan formula yang ada pada Fyson (1985):

$$
\begin{aligned}
C_{b} & =\frac{\nabla}{\left(L_{W L} \times B \times d\right)} \\
C_{p} & =\frac{\nabla}{A_{\mathrm{x}} \times L_{W L}} \\
C_{v p} & =\frac{\nabla}{\mathrm{A}_{\mathrm{W}} \times d} \\
C_{m} & =\frac{A_{x}}{d \times B_{W L}} \\
C_{W} & =\frac{\mathrm{A}_{\mathrm{w}}}{L_{W L} \times B}
\end{aligned}
$$

Keterangan:

$\mathrm{Cb} \quad$ : koefisien balok

$\mathrm{C}_{\mathrm{w}} \quad$ : koefisien prismatik

$\mathrm{C}_{\mathrm{vp}} \quad$ : koefisien prismatik tegak

$\mathrm{C}_{\mathrm{m}} \quad$ : koefisien penampang tegak

$\mathrm{C}_{\mathrm{w}} \quad$ : koefisien bidang air

$\nabla \quad$ : volume displacement $\left(\mathrm{m}^{3}\right)$

$A_{x} \quad$ luasan pada daerah tengah kapal $\left(\mathrm{m}^{2}\right)$

LwL : panjang garis air $(\mathrm{m})$

B : Breadth $(\mathrm{m})$ 
$A_{w} \quad:$ luasan/area pada garis air tertentu $\left(\mathrm{m}^{2}\right)$

d : draught atau sarat air $(\mathrm{m})$

Perhitungan tahanan kasko kapal menggunakan kecepatan laju kapal sebesar 7 knot. Kecepatan ini merupakan kecepatan dinas pada saat kapal melakukan kegiatan penangkapan ikan di laut. Perhitungan tahanan kasko pada kapal menggunakan persamaan berikut (Holtrop 1977):

$$
\begin{aligned}
& L_{R}=L W L \times \frac{(1-C p+0,06 \times C p \times L C B)}{4 \times C p-1} \\
& S=\left(\left(L W L \times(2 \times d+B) \times \sqrt{\mathrm{C}_{\otimes}}\right) \times((0,453+0,4425 \times C b-0,2862 \times\right. \\
& \left.\left.C_{\otimes}\right)\left(-0,003467 \times B / d^{+0,3696 \times C W)}\right)+\left(2,38 \times A_{B T} / C b\right)\right) \\
& C_{F}=\frac{0,075}{\left(\log 10\left(R_{n}\right)-2\right)^{2}} \\
& 1+k=0,93+\frac{\left(\frac{d}{L W L}\right)^{0,22284} \times\left(\frac{B}{L_{R}}\right)^{0,92497} \times(1-C p+0,0225 \times L C B)^{0,06906}}{(0,95-C p)^{0,521448}} \\
& R_{v}=1 / 2 \times \rho \times V^{2} \times C_{F} \times(1+k) \times S
\end{aligned}
$$

Keterangan:

LR : Panjang kapal untuk perhitungan tahanan kasko (m)

LCB : Longitudinal center buoyancy $(\mathrm{m})$

$\mathrm{S} \quad$ : Wetted surface area $\left(\mathrm{m}^{2}\right)$

Авт : Bulb area, karena kapal ikan tidak mempunyai bulbous bow, maka $\mathrm{A}_{\mathrm{BT}}=0$

Rn : Reynold's Number bergantung pada LWL kapal

$1+\mathrm{k} \quad$ : Untuk bentuk kapal yang bare hull atau single hull form

$\mathrm{V} \quad$ : Kecepatan (knot)

$\mathrm{Rv} \quad$ : Frictional resistance

$\mathrm{CF}_{\mathrm{F}} \quad$ : Frictional resistance coefficient

$\rho \quad$ : massa jenis air laut $(1,025)$

Gerak pitching kapal dihitung dengan persamaan berikut (Bhattacharyya, 1978 dalam Ivandri et al. 2017):

$$
a \frac{d^{2} \theta}{d t^{2}}+b \frac{d \theta}{d t}+c \theta=M_{\theta} \cos \omega_{\theta} t
$$

Keterangan:

$\begin{array}{ll}\mathrm{a} \frac{\mathrm{d}^{2} \theta}{\mathrm{dt}{ }^{2}} & : \text { Inertial moment } \\ \mathrm{b} \frac{\mathrm{d} \theta}{\mathrm{dt}} & : \text { Damping moment } \\ \mathrm{c} \theta & : \text { Restoring moment } \\ \mathrm{M}_{\theta} \cos \omega_{\theta} \mathrm{t}: & \text { The exciting moment }\end{array}$

Perhitungan gerak pitching kapal menggunakan simulasi numerik dengan dua sudut arah kedatangan gelombang yaitu bow seas dan head seas. Arah datang gelombang untuk bow seas digunakan sudut 135 derajat dan head seas adalah 180 derajat. Penggunaan kedua sudut ini merupakan arah kedatangan gelombang yang berpapasan langsung dengan bagian linggi haluan kapal. Selanjutnya disimulasikan menggunakan spektrum gelombang JONSWAP (Joint North Sea Wave Project) dengan variasi tiga ketinggian gelombang yaitu $1 \mathrm{~m}, 2 \mathrm{~m}$, dan 3,5 m. Ketiga gelombang tersebut merupakan perwakilan dari tinggi gelombang pada daerah penangkapan ikan. Menurut Hutauruk dan Rengi (2014), spektrum ini menggambarkan kondisi angin laut yang identik dengan kondisi laut di Indonesia, 
dan sebagai model matematik spektrum yang didasari pada beberapa parameter, salah satunya adalah tinggi gelombang signifikan. Romadoni (2016) juga menyatakan bahwa JONSWAP juga mengawasi perhitungan oseanografis yang ekstensif pada jenis perairan kepulauan/tertutup. Dalam hal ini Indonesia termasuk dalam salah satu jenis perairannya.
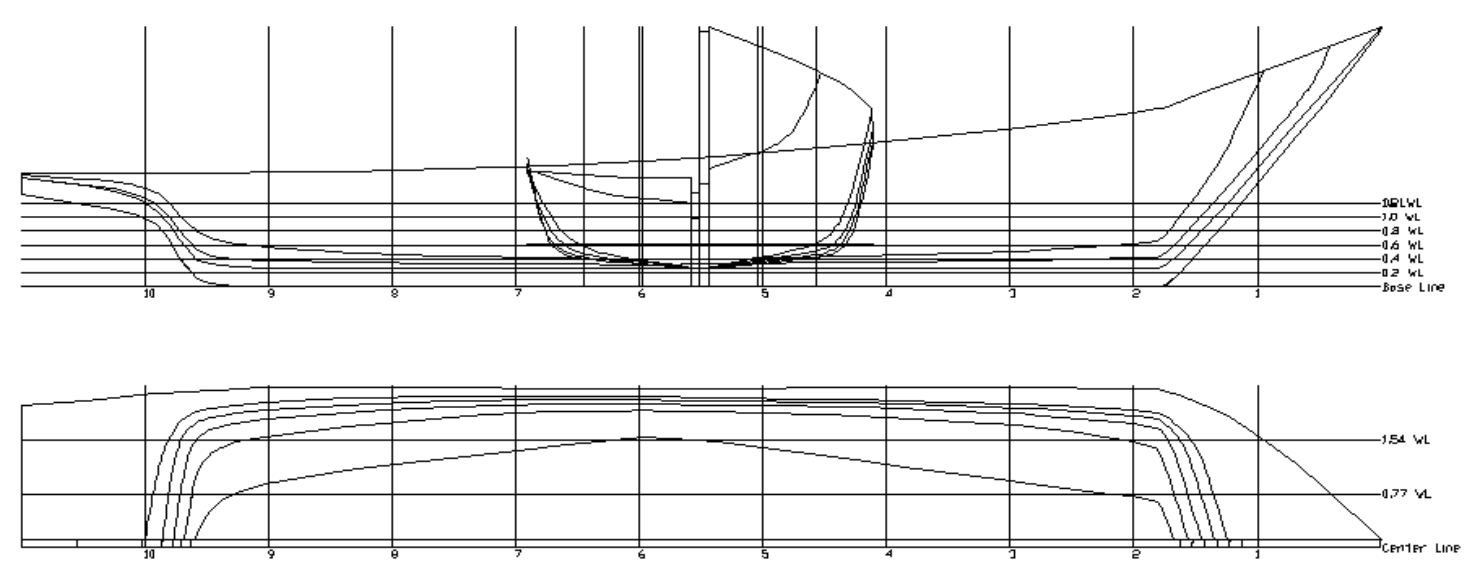

Gambar 1 Bentuk linggi haluan kapal RBT
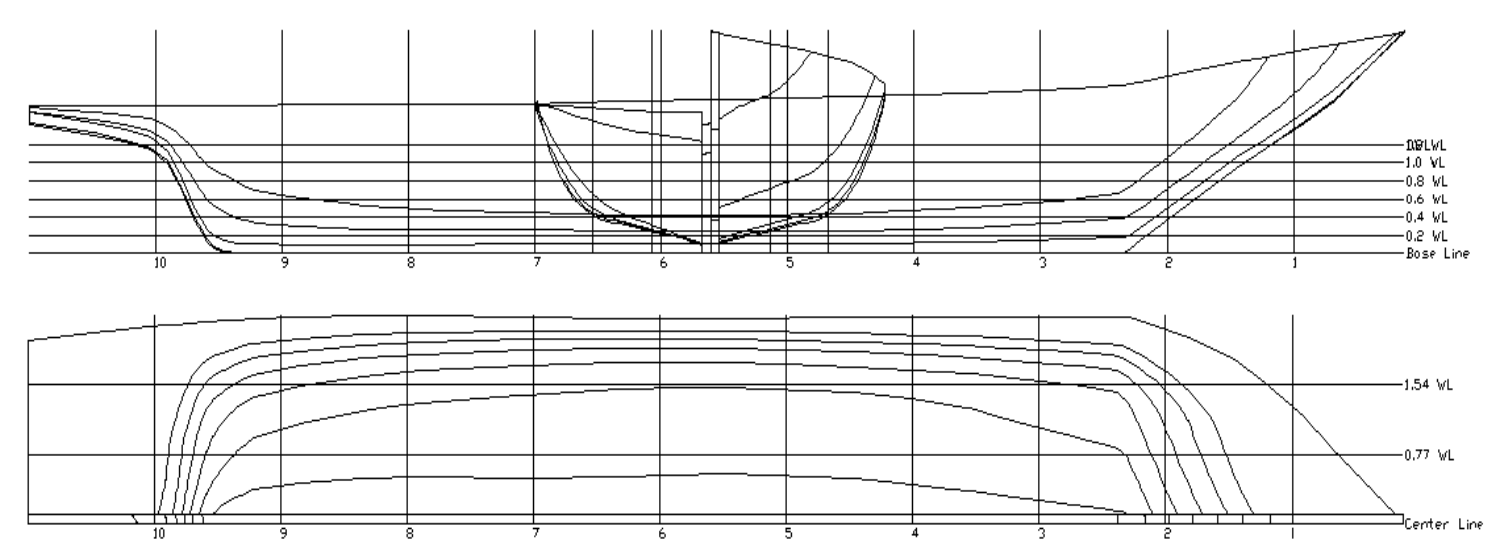

Gambar 2. Bentuk linggi haluan kapal RBL
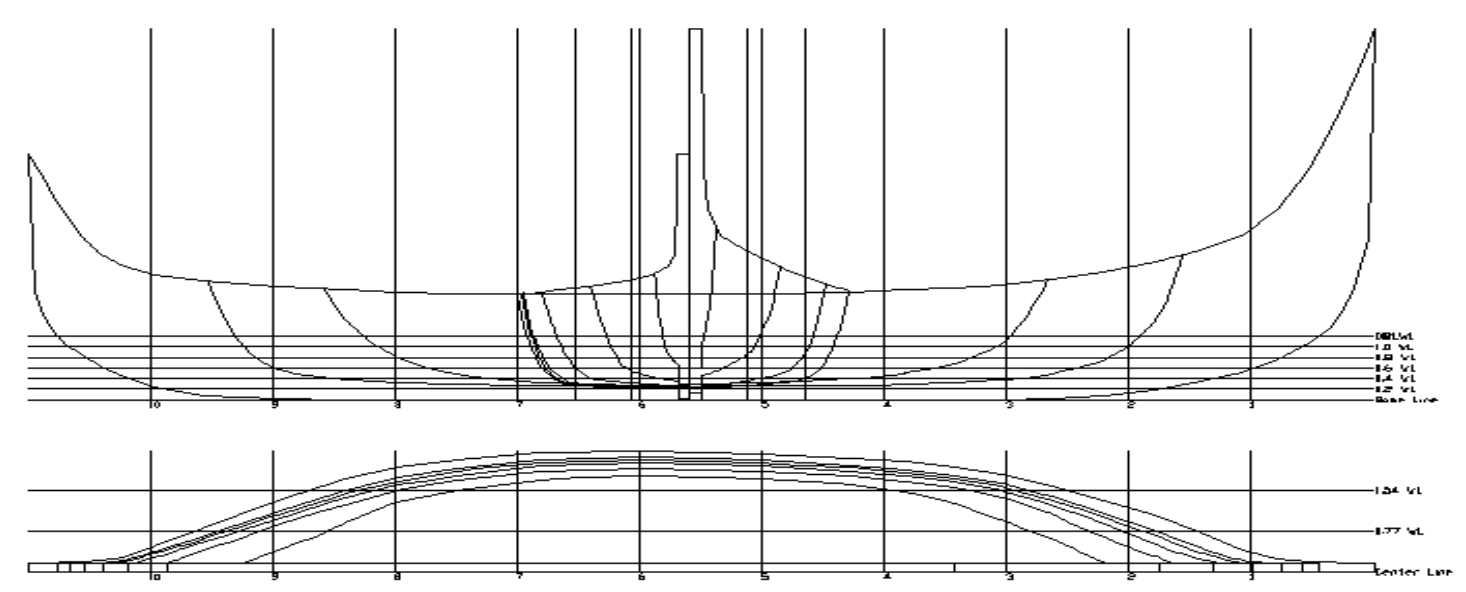

Gambar 3 Bentuk linggi haluan kapal SB 


\section{HASIL DAN PEMBAHASAN}

Berbeda bentuk linggi haluan kapal maka berbeda pula kinerja kapal yang dihasilkan. Berikut ini disajikan hasil perhitungan coefficient of fineness (Tabel 1), tahanan gerak kapal dan wetted surface area (Gambar 4 dan Tabel 2), dan performa gerak pitching kapal (Gambar 5, Tabel 3 dan Gambar 6).

Tabel 1 Coefficient of fineness kapal

\begin{tabular}{lccc}
\hline \multirow{2}{*}{ Parameter } & \multicolumn{3}{c}{ U-bottom } \\
\cline { 2 - 4 } & RBT & RBL & SB \\
\hline Coeficient block $\left(C_{b}\right)$ & 0.578 & 0.550 & 0.435 \\
Coeficient prismatic $\left(C_{p}\right)$ & 0.834 & 0.794 & 0.587 \\
Coeficient vertical prismatic $\left(C_{v p}\right)$ & 0.637 & 0.624 & 0.673 \\
Coeficient midship $\left(C_{m}\right)$ & 0.696 & 0.696 & 0.740 \\
Coeficient waterplan $\left(C_{w}\right)$ & 0.908 & 0.882 & 0.645 \\
\hline
\end{tabular}

Ditinjau berdasarkan besarnya nilai coefficient of fineness, kapal dengan bentuk linggi haluan RBT memiliki nilai $\mathrm{C}_{b}, \mathrm{C}_{\mathrm{p}}$, dan $\mathrm{C}_{\mathrm{w}}$ tertinggi dan diikuti oleh kapal dengan bentuk linggi haluan RBL dan terakhir kapal dengan bentuk linggi haluan SB. Hal ini disebabkan oleh besarnya volume displacement dan water plan area $\left(\mathrm{A}_{\mathrm{w}}\right)$ pada kapal dengan linggi haluan $\mathrm{RBT}$ lebih besarnya dibandingkan pada kapal dengan linggi haluan RBL dan SB. Nilai volume displacement dan $\mathrm{A}_{\mathrm{w}}$ berbanding lurus dengan nilai $\mathrm{C}_{\mathrm{b}}, \mathrm{C}_{\mathrm{p}}$, dan $\mathrm{C}_{\mathrm{m}}$ (Fyson 1985). Artinya jika semakin besar nilai volume displacement, dan $\mathrm{A}_{\mathrm{w}}$ maka nilai $\mathrm{C}_{\mathrm{b}}, \mathrm{C}_{\mathrm{p}}$, dan $\mathrm{C}_{\mathrm{w}}$ akan meningkat.

Lain halnya dengan nilai $C_{v p}$ dan $C_{m}$ menunjukkan fenomena yang berbeda. Hal ini dikarenakan nilai sarat air (d), $A_{w}$ dan BwL lebih tinggi dibandingkan volume displacement dan Ax. Nilai sarat air (d), $A_{w}$ dan Bws berbanding terbalik dengan nilai $C_{v p}$ dan $C_{x}$ (Fyson 1985). Artinya jika semakin tinggi nilai d, $A_{w}$ dan $B$, maka nilai $C_{v p}$ dan $C_{x}$ akan menurun.

Perbedaan bentuk linggi haluan akan berpengaruh terhadap volume displacement kapal, sehingga dapat menghasilkan nilai coefficient of fineness yang berbeda pula. Kantu et al. (2013) juga menyatakan bahwa kapal yang memiliki nilai koefisien prismatik yang besar, akan memiliki luas bidang penampang melintang tengah kapal yang besar, sehingga bentuk lambungnya akan semakin melebar sampai pada bagian buritan kapal. Nilai coefficient of fineness khususnya $C_{B}, C_{P}, C_{w}$ dan $C_{x}$ akan mempengaruhi nilai tahanan kasko.

Tabel 2 Luas area yang terbenam air (wetted surface area) pada setiap bentuk linggi haluan kapal

\begin{tabular}{cccc}
\hline \multirow{2}{*}{ Parameter } & \multicolumn{3}{c}{ U-bottom } \\
\cline { 2 - 4 } & RBT & RBL & SB \\
\hline Wetted surface area $\left(\mathrm{m}^{2}\right)$ & 86.9619 & 82.5291 & 78.3459 \\
\hline
\end{tabular}

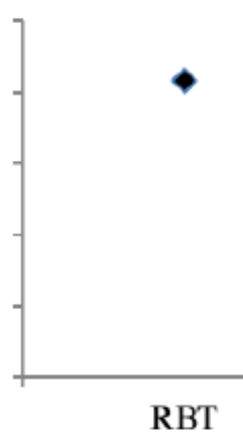

RBL

Bentuk linggi haluan kapal 
Gambar 4 Tahanan kasko setiap bentuk linggi haluan

Hasil perhitungan wetted surface area (Tabel 2) dan tahanan kasko (Gambar 4) yang diperoleh hasil yang berbeda antar setiap bentuk linggi haluan, walaupun setiap kapal memiliki dimensi yang sama (LOA, B, dan D). Terlihat bahwa wetted surface area dan tahanan terbesar diperoleh pada bentuk linggi haluan RBT, diikuti oleh bentuk linggi haluan RBL dan SB. Hal ini disebabkan oleh besarnya nilai LR (panjang kapal untuk perhitungan tahanan kasko), bilangan Reynold's (Rn), Frictional resistance coefficient ( $\mathrm{CF}_{\mathrm{F}}$ ) dan Longitudinal center buoyancy (LCB). Holtrop (1977) juga menyatakan bahwa besarnya nilai wetted surface area dipengaruhi oleh besarnya nilai $\mathrm{L}_{w 1}, \mathrm{C}_{\mathrm{x}}, \mathrm{C}_{\mathrm{b}}$, dan $\mathrm{C}_{\mathrm{w}}$ pada suatu kapal. Semakin besar nilai wetted surface area, semakin besar pula tahanan yang diperoleh. Berdasarkan beberapa parameter diatas, terdapat kecenderungan bahwa bentuk linggi haluan kapal berpengaruh terhadap tahanan gerak yang dihasilkannya. Hal yang sama juga dikemukakan oleh Manopo et al. (2012), bahwa perbedaan tahanan kasko disebabkan oleh perbedaan koefisien bentuk (coefficient of fineness), ukuran utama (LR), dan luas permukaan basah kapal (S).

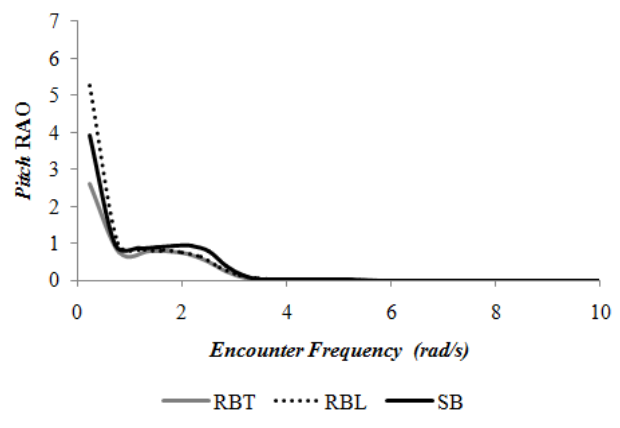

(a) 135 degree

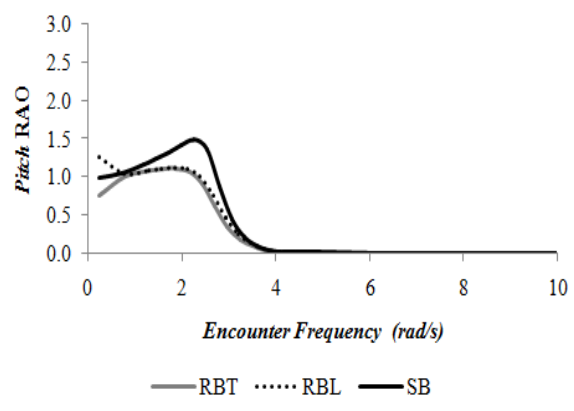

(b) 180 degree

Gambar 5 Performa pitch Response Amplitude Operator (RAO) pada setiap bentuk linggi haluan kapal terhadap arah kedatangan gelombang

Tabel 3 Performa pitch motion pada setiap ketinggian gelombang

\begin{tabular}{llll}
\hline \multirow{2}{*}{ Parameter } & \multicolumn{3}{c}{ U-bottom } \\
\cline { 2 - 4 } & $\mathrm{RBT}$ & $\mathrm{RBL}$ & $\mathrm{SB}$ \\
\hline Sudut kedatangan $=135$ derajat & & & \\
\hline Pitch $R A O$ maximum & 2.62 & 5.27 & 3.92 \\
Encounter frequency maximum & 8,57 & 12.01 & 7,58 \\
Pitch motion: & & & \\
Hw1 $=1 \mathrm{~m}($ deg $)$ & 0.82 & 0.94 & 0.94 \\
Hw2 $=2 \mathrm{~m}($ deg $)$ & 1.63 & 1.88 & 1.88 \\
Hw3 $=3 \mathrm{~m}($ deg $)$ & 2.86 & 3.30 & 3.30 \\
& & & \\
\hline Sudut kedatangan $=180$ derajat & & & \\
\hline Pitch RAO maximum & 1.12 & 1.26 & 1.49 \\
Encounter frequency maximum & 9.75 & 11.24 & 9.39 \\
Pitch motion: & & & \\
Hw1 $=1 \mathrm{~m}($ deg $)$ & 1.02 & 1.06 & 1.25 \\
Hw2 $=2 \mathrm{~m}($ deg $)$ & 2.04 & 2.13 & 2.50 \\
Hw3 $=3 \mathrm{~m}($ deg $)$ & 3.57 & 3.72 & 4.37 \\
\hline
\end{tabular}




\section{Pitch motion pada arah kedatangan sudut 135 dan 180 dejarat}

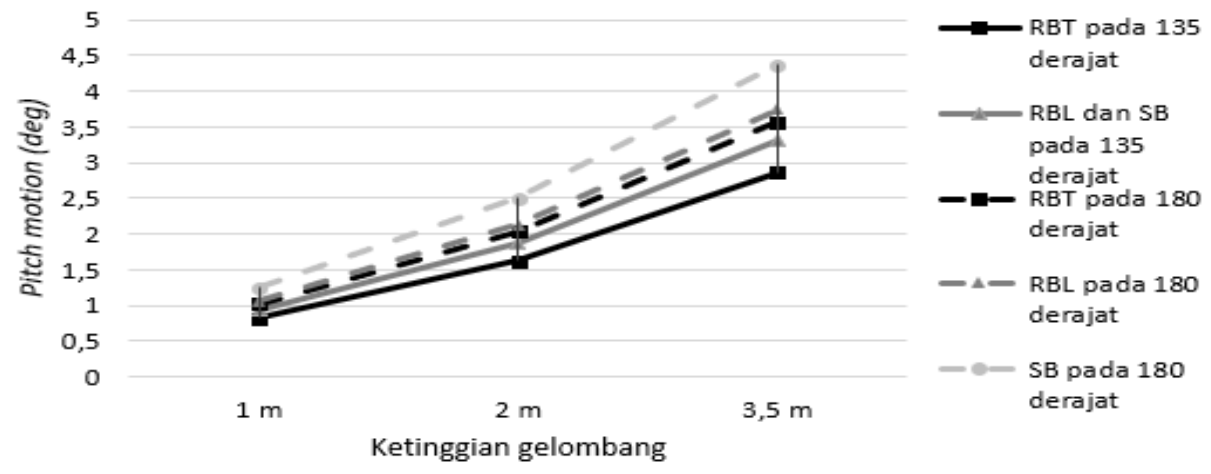

Gambar 6 Pitch motion pada setiap arah sudut kedatangan gelombang terhadap ketinggian gelombang

Secara umum pola pergerakan yang dihasilkan pada pitch $R A O$ berdasarkan arah kedatangan gelombang (Gambar 5) tidak memiliki kecenderungan terhadap bentuk linggi haluan kapal. Namun jika ditinjau berdasarkan besaran nilai pada setiap pitch $R A O$ terdapat perbedaan (Tabel 3). Berdasarkan grafik pitch RAO pada sudut kedatangan 135 derajat atau bowseas (Gambar 5a) dan nilai pitch RAO maksimum (Tabel 3), terdapat kecenderungan bahwa bentuk linggi haluan RBL memiliki nilai pitch $R A O$ terbesar, dan disusul oleh bentuk linggi haluan SB dan RBT.

Lain halnya pada pitch $R A O$ dengan arah sudut kedatangan gelombang 180 derajat atau headseas (Gambar 5b) dan nilai pitch RAO maksimum (Tabel 3), terlihat bahwa bentuk linggi haluan SB memiliki nilai pitch $R A O$ terbesar, dan disusul oleh bentuk linggi haluan RBL dan RBT. Mengacu pada Bhattacharyya (1978) besarnya nilai pitch $R A O$ dipengaruhi oleh besarnya nilai panjang gelombang, frekuensi gelombang, dan encounter frequency. Pada saat terjadi gelombang dengan periode pendek, maka semakin cepat frekuensi papasan dari gelombang. Ketika frekuensi gelombang semakin besar atau kapal semakin sering terkena gelombang, maka dapat mengakibatkan ketidakseimbangan pada bagian haluan kapal.

Pada kapal dengan linggi RBT dan SB yang dioperasikan di perairan dengan periode gelombang pendek dan cepat, maka akan cenderung menghasilkan respon pitch $\mathrm{RAO}$ yang lebih besar, untuk dapat mempertahankan posisi keseimbang pada bagian haluannya. Sehingga dalam hal ini, bentuk linggi haluan RBT dan SB sebaiknya digunakan pada perairan dengan periode gelombang yang lambat

Besarnya kedua arah sudut kedatangan gelombang (135 derajat dan 180 derajat), menghasilkan nilai pitch $R A O$ yang berbeda pada setiap bentuk linggi haluan. Hal ini menunjukkan bahwa tidak hanya panjang gelombang, frekuensi gelombang, dan encounter frequency yang berpengaruh terhadap pergerakan pitching, namun besarnya arah sudut kedatangan gelombang juga dapat berpengaruh. Selain itu, respon pitch $R A O$ juga dipengaruhi oleh bentuk kasko dan coefficient of fineness (khususnya nilai Cvp) (Bhattacharyya 1978).

Hasil simulasi gerak pitching (Gambar 6) pada ketiga tinggi gelombang (1m, 2m, 3,5m) menghasilkan nilai yang berbeda-beda. Bentuk linggi haluan SB, memiliki kecenderungan nilai pitch motion terbesar, dan disusul oleh bentuk linggi haluan RBL dan RBT. Hal ini terjadi pada kedua arah sudut kedatangan gelombang (135 derajat dan 180 derajat). Artinya kapal dengan linggi haluan SB jika dioperasikan pada tinggi gelombang yang semakin besar, akan menghasilkan pitch motion yang semakin besar juga. Bhattacharyya (1978), menyatakan bahwa besar kecilnya pitch motion yang dihasilkan disebabkan oleh adanya inertial moment, damping moment, restoring moment, dan the exciting moment. Perbedaan arah sudut kedatangan gelombang yang berpapasan dengan kapal dan tinggi gelombang laut menghasilkan nilai yang berbeda-beda. Semakin besar sudut kedatangan 
gelombang dan semakin besar tinggi gelombang yang berpapasan dengan kapal akan menghasilkan gerakan pitching yang semakin besar juga. Hal ini sesuai dengan pernyataan Rosmani dan Bochary (2016) bahwa kenaikan sudut kedatangan gelombang akan menghasilkan gerakan pitching yang semakin besar juga.

\section{KESIMPULAN DAN SARAN}

Penggunaan bentuk linggi haluan RBT cenderung menghasilkan nilai $\mathrm{Cb}, \mathrm{Cp}, \mathrm{Cw}$, dan tahanan gesek yang lebih besar, namun menghasilkan performa gerakan pitching yang lebih kecil dibandingkan RBL dan SB. Kapal dengan bentuk linggi haluan ini dapat digunakan untuk kapal yang beroperasi di perairan dengan periode gelombang lambat dan cepat. Penggunaan bentuk linggi haluan SB cenderung menghasilkan nilai Cvp dan $\mathrm{Cm}$ yang lebih besar, serta menghasilkan performa gerakan pitching yang lebih besar dibandingkan RBT dan RBL. Bentuk linggi haluan RBL yang memiliki nilai yang berada diantara nilai-nilai pada bentuk linggi RBT dan SB. Kapal dengan bentuk linggi SB dan RBL disarankan untuk dipergunakan pada kapal yang beroperasi di perairan dengan karakteristik gelombang dengan periode lambat.

Dalam penelitian ini masih perlu dikaji lebih lanjut terkait kinerja kapal dan stabilitasnya berdasarkan bentuk linggi haluan kapalnya, sehingga dapat menghasilkan kapal yang layak dioperasikan sesuai dengan jenis alat tangkap yang digunakan serta daerah penangkapannya.

\section{DAFTAR PUSTAKA}

Bangun, T. N. C., Novita Y., Iskandar B. H. 2017. Bentuk Linggi Haluan Kapal Penangkap Ikan (Kurang dari 30 GT). Albacore, 1(2): 127-137.

Bhattacharyya, R. 1978. Dynamics of Marine Vehicles, John Wiley \& Sons Inc, New York.

Dariansyah, M. R., Iskandar, B. H., Novita, Y. 2017. Bentuk Kasko dan Pengaruhnya Terhadap Kapasitas Volume Ruang Muat dan Tahanan Kasko. Albacore, 1(3): 265-276.

Dariansyah, M. R., Iskandar, B. H., Novita, Y. 2020. Bentuk Kasko dan Pengaruhnya terhadap stabilitas dan Area Putar Kapal. Jurnal Sains dan teknologi, 10(3): 6-17.

Djatmiko, S., Citrodijoyo, S., Hartono. 1983. Tahanan Penggerak Kapal, Departemen Pendidikan dan Kebudayaan. Jakarta.

Fyson, J. 1985. Design of Small Fishing Vessels, Fishing News Book, England.

Holtrop, J. 1977. A Statistical Analysis of Performance Test Result. International Shipbuilding Progress, 24(270): 23-28.

Hutauruk, R.M., Rengi, P. 2014. Respon Gerakan Kapal Perikanan Hasil Optimasi Terhadap Gelombang, JPK, 19(1): 13-22.

Ivandri, H., Mulyatno I. P., Kiryanto, K. 2017 Analisa Pengaruh Kedalaman, Arus, serta Tinggi Gelombang Perairan Terhadap Olah Gerak Kapal. Jurnal Teknik Perkapalan, 5(4): 785-791.

Kantu, L., Kalangi, P. N. I., Polii, J. F. 2013. Desain dan Parameter Hidrostatik Kasko Kapal Fiberglass Tipe Pukat Cincin 30 GT di galangan Kapal CV Cipta Bahari Nusantara Minahasa Sulawesi Utara. Jurnal Ilmu dan Teknik Perikanan Tangkap, 1(3): 81-86.

Ma'ruf, A., Pranatal, E. 2020. Analisa Seakeeping Kapal Pembersih Sampah (Trash Skimmer) di wilayah Perairan Teluk Sumenep. Seminar Teknologi Kebumian dan Kelauitan (SEMITAN II) Institut Teknologi Adhi Tama Surabaya (ITATS). 2(1): 313-318. 
Manopo, A. R., Masengi, K. W. A., Pamikiran R. D. C. 2012. Studi Pengaruh Bentuk Kasko pada Tahanan Kapal Pukat Cincin di Tumumpa, Bitung, dan Molibagu (Provinsi Sulawesi Utara). Jurnal Ilmu dan Teknologi Perikanan Tangkap, 1(2): 63-68.

Putra, P. K. D. N. Y., Akbarsyah, N., Permana, R., Andhikawati, A., Novita, Y., Iskandar, B. H. 2020. Karakteristik kapal Rawai Berdasarkan Rasio Dimensi Utama di Pelabuhan Perikanan Nusantara Brondong kabupaten Lamongan. Jurnal Akuatek, 1(1): 53-58.

Romadhoni. 2016. Analisa Olah Gerak Kapal di Gelombang Reguler pada Kapal Tipe Axe Bow. Kapal, 13(2): 61-68.

Rosmani, Bochary L. 2016. Jurnal Riset dan Teknologi Kelautan, 14(1): 23-38. 